\title{
PENGGUNAAN TEKNOLOGI INFORMASI DAN KINERJA AUDITOR
}

\author{
Yohanis Tasik Allo ${ }^{1}$, Anthon Paranoan ${ }^{1}$, Yeheschiel Bartin Marewa ${ }^{1}$ \\ ${ }^{1}$ Dosen UKI Paulus Makassar
}

\begin{abstract}
This study aimed to examine the effect of the information technology application on auditors performance in KAP Makassar. This study performed to the public auditor working in KAP. Data collection will be done with the survey taken from $K A P$ in Makassar by 45 respondents through questionnaires and using proportional random sampling. Test of data quality used validity test and reliability test. Prerequisite test analysis using multicolinierity test, heteroscedasticity test, normality test, and test linieritas.Teknik data analysis will use descriptive analysis, simple regression test and multiple regression. The result of this research indicates that the application of information technology which is represented by three independent variables, skill and knowledge, system usage and perceived usefulness, has a positive and significant influence about the auditor's performance. The findings of this study recommends increased in information technology usage so that the effectiveness and efficiency of the audit process can be improved.
\end{abstract}

Keywords: Application of IT, Skills and Knowledge, System Usage, Perceived Usefulness, Auditor's Performance

\begin{abstract}
ABSTRAK
Penelitian ini bertujuan untuk menguji pengaruh penerapan teknologi informasi terhadap kinerja auditor di KAP Kota Makassar. Penelitian ini dilakukan terhadap para auditor publik yang bekerja di KAP. Pengumpulan data akan dilakukan dengan survey yang diambil dari KAP di Kota Makassar sebanyak 45 responden melalui kuisioner dan menggunakan proportional random sampling. Uji keabsahan data menggunakan uji validitas, reliabilitas. Uji prasyarat analisis menggunakan uji multikolinieritas, uji heteroskedastisitas, uji normalitas, dan uji linieritas.Teknik analisis data akan menggunakan analisis deskripsi, uji regresi sederhana dan regresi berganda. Hasil penelitian ini menunjukkan bahwa penerapan teknologi informasi, yang mencakup pengetahuan dan kemampuan auditor dalam bidang teknologi informasi (skill and knowledge), penggunaan sistem (system usage), serta persepsi penggunaan (perceived usefulness) menunjukkan pengaruh yang positif dan signifikan terhadap kinerja auditor. Temuan ini dapat meningkatkan pengguaan teknologi informasi sehingga dapat meningkatkan efektifitas dan efisiensi dalam proses audit.
\end{abstract}

Kata kunci: Penerapan TI, Skill and Knowledge, System Usage, Perceived Usefulness, Kinerja Auditor

Jurnal Akun Nabelo: Jurnal Akuntansi Netral, Akuntabel, Objektif Volume 1/Nomor 1/Juli 2018 Jurusan Akuntansi FE-Universitas Tadulako

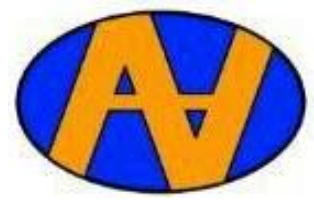




\section{A. PENDAHULUAN}

Teknologi informasi yang berkembang sedemikian pesat saat ini membawa dampak dalam kehidupan masyarakat. Hampir semua bidang telah memanfaatkan kemajuan teknologi informasi dalam kegiatannya. Penggunaan teknologi informasi membuat kegiatan bisnis menjadi efektif dan efisien karena pelaku bisnis dapat memperoleh informasi dengan cepat dan biaya yang relatif rendah. Demikian juga dengan auditor di Kantor Akuntan Publik (KAP) membutuhkan TI untuk mendukung kinerja mereka.

Keberhasilan kinerja auditor juga tidak terlepas dari tersedianya teknologi informasi (TI) yang dibutuhkan dalam pelaksanaan audit. Dalam melakukan audit, auditor berhadapan dengan sebuah sistem pengendalian intern di mana pada saat ini auditee sudah banyak yang menerapkan sistem teknologi informasi yang berbeda-beda. Menurut Budiasih (2008), auditor akan berhadapan dengan keberadaan sebuah pengendalian internal yang kompleks karena teknologi yang melekat dan sangat berbeda dengan pengendalian sistem manual. Dalam proses pengembangan sebuah sistem, maka diperlukan pengendalian lewat berbagai "testing program" yang mungkin tidak ditemui dalam sistem manual. Perangkat keras maupun lunak terus berkembang secara cepat seiring perkembangan teknologi. Hal ini akan menimbulkan kesenjangan waktu antara teknologi yang dipelajari oleh auditor dengan perkembangan teknologi yang cepat. Walaupun auditor harus berhadapan dengan perkembangan teknologi yang cepat, tetapi dalam pelaksanaan audit, auditor diharapkan dapat menerapkan teknologi informasi dalam melakukan proses pemeriksaan agar pemeriksaan dapat diselesaikan tepat waktu dan dapat meningkatkan kualitas laporan hasil pemeriksaan. Apabila laporan hasil audit yang disajikan tidak terlambat dan berkualitas, tentu hal ini akan berdampak pada peningkatan kinerja auditor. Selain itu, dengan adanya penambahan perangkat teknologi informasi dan berbagai pelatihan diharapkan kepada auditor agar teknologi informasi yang ada bukan hanya mampu digunakan namun mampu diimplementasikan dalam melakukan pemeriksaan. Kesuksesan dari pelaksanaan audit akan mampu meningkatkan kinerja auditor.

Selain teknologi informasi (TI), auditor juga perlu menguasai pemahaman mengenai pengendalian internal (internal control-IC) dan sistem informasi (information system-IS) yang diadopsi oleh KAP tempat auditor tersebut bekerja. Masing-masing KAP memiliki kebijakan yang berbeda mengenai teknologi dan sistem informasi yang digunakannya dalam rangka memudahkan penugasannya dalam menyelesaikan proses audit. Galung (2009) menyatakan bahwa defisiensi atau kekurangan TI yang tidak pernah dilaporkan sebelumnya sekarang menjadi sorotan dan menjadi target untuk evaluasi dan perbaikan, juga disebutkan bahwa hasil penelitian mengindikasikan bahwa defisiensi atau kekurangan TI dan error dalam pencatatan lebih sering terjadi dalam perusahaan dimana terdapat defisiensi TI. Elsya (2008) mengatakan bahwa kerumitan lingkungan teknologi informasi (TI) klien auditor barubaru ini mengharuskan tanggung jawab lebih jauh dari auditor untuk mendeteksi risiko inheren, risiko pengendalian dan fraud, laporan CEO dari enam kantor akuntan internasional bahwa mereka tidak merasa usaha deteksi risiko saat ini sesuai. Fleenor (2002) juga mengatakan bahwa "...penggunaan teknologi yang semakin meluas menyulitkan auditor dalam menemukan kejahatan...". Tanriverdi (2006) dalam Gautama (2010) mengatakan bahwa risiko audit yang berkaitan dengan lingkungan TI terintegrasi dengan sistem pengendalian internal. Reliabilitas atau keandalan dari 
sistem informasi akuntansi secara signifikan bergantung pada desain dan pemeliharaan sistem pengendalian internal yang terkomputerisasi. Pada gilirannya, sistem pengendalian internal yang terdesain dengan baik penting untuk keberhasilan perusahaan dalam tujuan strategisnya.

Sebagai suatu badan atau organisasi, KAP pun turut menerapkan sistem teknologi informasi dalam pekerjaannya. Pengaplikasian atau pengadopsian sistem teknologi informasi ini bertujuan untuk mendatangkan efisiensi dan efektivitas pada kinerja auditor. Auditor atau para staf auditor dituntut untuk menguasai teknologi informasi atau sistem informasi yang diadopsi oleh KAP tempatnya bekerja. IFAC (2010) mengharuskan auditor untuk memiliki keahlian dan pengetahuan teknis, termasuk pengetahuan teknologi informasi yang relevan. Lebih lanjut, dalam Appendix 1 dari IFAC juga disebutkan bahwa tingkat kerentanan yang tinggi atas perubahan yang cepat seperti perubahan dalam teknologi merupakan faktor risiko terkait dengan salah saji yang timbul dari kecurangan finansial.

Penelitian sebelumnya menemukan bahwa Group Decision Support Systems (GDSS) atau Group Support Systems (GSS) dalam konteks sistem informasi dapat membantu auditor dalam membuat keputusan audit yang lebih efisien dan efektif. Herusetya (2011) juga mengatakan bahwa decision aids dan teknologi informasi dapat meningkatkan kualitas audit atau kinerja penugasan auditor dengan meningkatkan kecenderungan auditor untuk mendeteksi dan melaporkan salah saji laporan keuangan.

Tugas sebagai seorang auditor tidak lepas dari bantuan teknologi antara lain untuk membangun komunikasi baik dengan klien maupun rekan satu tim, untuk menyelesaikan rangkaian proses audit hingga membuat laporan audit dengan bantuan software tertentu dan untuk menyimpan filefile penting yang berhubungan dengan pekerjaan. Selain memanfaatkan fasilitas teknologi informasi yang lazim digunakan seperti misalnya surat elektronik dan telepon, setiap KAP biasanya juga menggunakan suatu software khusus yang berguna untuk memfasilitasi pelaksanaan audit.

Penelitian sebelumnya yaitu yang dilakukan oleh Herusetya (2011) menguji secara khusus apakah auditor dari KAP yang berafiliasi dengan the Big 4 di Indonesia telah memberdayakan sistem informasi teknologi, baik dalam bentuk GSS atau audit support system, maupun bentuk perangkat lunak teknologi informasi lainnya guna meningkatkan task performance sebagai bentuk dari audit decision quality. Dalam penelitian sebelumnya ditemukan bukti bahwa auditor yang tidak berpengalaman berbeda dalam menggunakan informasi yang tersedia dalam mendeteksi masalah, dibandingkan dengan auditor berpengalaman.

Pennington et al. (2006) dalam Herusetya (2011) menjelaskan bahwa penelitian lainnya dalam area technology acceptance model (TAM) menemukan bahwa jika perceived ease of use rendah maka qualitative overload akan meningkat karena individu memandang penugasan audit lebih sulit dan merasa kurang terampil dalam menggunakan sistem sehingga memberikan efek negatif dalam penggunaan sistem informasi teknologi yang dimaksudkan. Dengan kata lain, persepsi bahwa sistem informasi elektronik sulit mengakibatkan berkurangnya pemberdayaan sistem tersebut.

Penelitian ini mengacu kepada penelitian sebelumnya oleh Herusetya (2011) yang ingin menguji apakah penggunaan sistem informasi teknologi elektronik dalam rangka membantu penugasan auditor yang kompleks, memiliki pengaruh positif terhadap kinerja auditor dengan sampel auditor dari KAP besar the Big 4. Penelitian ini 
juga memiliki tujuan yang sedikit berbeda dari penelitian sebelumnya, yaitu ingin menguji apakah sistem teknologi informasi yang diadopsi oleh KAP mempengaruhi kinerja auditor. Sampel yang digunakan dalam penelitian ini berasal dari populasi KAP yang terdapat di Kota Makassar yang dipilih dengan pertimbangan antara lain agar tidak mengulang penelitian serupa pada lingkup populasi yang sama seperti penelitian sebelumnya yaitu KAP the Big 4 yang berada di Daerah Khusus Ibukota Jakarta dan sekitarnya. Alasan selanjutnya yaitu karena Makassar sebagai ibukota Propinsi Sulawesi Selatan merupakan pusat bisnis dan industri.

Berdasarkan penjelasan di atas, penelitian ini bertujuan untuk menguji apakah faktor-faktor sistem teknologi informasi, yaitu skill and knowledge staf auditor, system usage atau information system use, dan perceived usefulness, memiliki pengaruh terhadap auditor's performance atau kinerja auditor. Penelitian ini juga bertujuan untuk mengetahui pengaruh keahlian dan pengetahuan staf auditor dalam bidang TI terhadap kinerja auditor, pengaruh pemanfaatan sistem informasi dan teknologi informasi terhadap kinerja auditor dan seberapa besar persepsi keyakinan staf auditor atas kegunaan teknologi informasi berpengaruh terhadap kinerja auditor.

Secara teoritis, hasil dari penelitian ini diharapkan dapat memberikan kontribusi bagi pengembangan ilmu pengetahuan di bidang akuntansi, terutama berkaitan dengan sistem informasi akuntansi. Selain itu, penelitian ini juga diharapkan dapat menambah wawasan bagi peneliti selanjutnya terkait literatur akuntansi mengenai pengaruh teknologi informasi terhadap kinerja auditor. Secara praktis, hasil penelitian ini diharapkan memberikan konstribusi kepada pihak perusahaan berkaitan dengan skill and knowledge staf auditor, system usage atau information system use, dan perceived usefulness, dan auditor's performance.

\section{B. TELAAH PUSTAKA DAN HIPOTESIS}

\section{B.1 Kinerja Auditor}

Kinerja merupakan salah satu ukuran keberhasilan dari suatu organisasi. Menurut Mangkunegara (2005), kinerja (prestasi kerja) adalah hasil kerja secara kualitas dan kuantitas yang dicapai oleh seseorang dalam melaksanakan tugasnya sesuai dengan tanggung jawab yang diberikan kepadanya. Selain itu, kinerja juga dapat diartikan sebagai suatu hasil kerja yang dihasilkan oleh seorang karyawan untuk mencapai tujuan yang diharapkan. Sementara itu, Suaib (2008) mengungkapkan bahwa kinerja seseorang merupakan kombinasi dari kemampuan, usaha dan kesempatan yang dapat dinilai dari hasil kerjanya. Kinerja (performance) adalah gambaran mengenai tingkat pencapaian suatu kegiatan/ program/kebijakan dalam mewujudkan sasaran, tujuan, visi dan misi organisasi yang tertuang dalam perencanaan strategis suatu organisasi.

Sementara itu, auditor adalah seseorang yang memiliki kualifikasi tertentu dalam melakukan audit atas laporan keuangan dan kegiatan suatu perusahaan atau organisasi. Terdapat tiga jenis auditor, yaitu auditor internal, auditor pemerintah dan auditor independen (akuntan publik). Auditor internal berfokus pada tugas membantu manajemen perusahaan tempatnya bekerja. Auditor internal bekerja pada suatu perusahaan dan berstatus sebagai pegawai di perusahaan yang sama. Selanjutnya auditor pemerintah, auditor pemerintah merupakan auditor yang bertugas melakukan audit atas keuangan pada instansiinstansi pemerintah. Di Indonesia, contoh auditor pemerintah adalah Badan Pemeriksa Keuangan (BPK). Jenis auditor yang terakhir yaitu auditor independen atau akuntan publik. Auditor independen 
bertugas mengaudit laporan keuangan yang diterbitkan oleh perusahaan. Pengauditan ini dapat dilakukan pada perusahaan go public, perusahaan besar maupun kecil dan organisasi non profit. Praktik akuntan publik ini harus bernaung di dalam suatu KAP.

Selain ketiga jenis auditor yang dijelaskan pada paragraf sebelumnya, Arens dan Loebecke (2011) menambahkan satu lagi jenis auditor yaitu auditor pajak. Di Indonesia, yang bertanggung jawab atas penerimaan negara dari sektor perpajakan dan penegakkan hukum dalam ketentuan perpajakan adalah Direktorat Jenderal Pajak (DJP) di bawah Departemen Keuangan RI. Aparat pelaksana DJP di lapangan adalah Kantor Pelayanan Pajak (KPP) dan Kantor Pemeriksaan dan Penyidikan Pajak (Karikpa). Tanggung jawab Karikpa adalah melakukan audit terhadap para wajib pajak tertentu untuk menilai apakah telah memenuhi ketentuan perundang-undangan perpajakan.

Kinerja auditor merupakan suatu pencapaian hasil kerja oleh seorang auditor. Galung (2009) mengemukakan bahwa kinerja auditor merupakan sebagai evaluasi terhadap pekerjaan yang dilakukan oleh atasan, rekan kerja, diri sendiri dan bawahan langsung. Dari pengertian di atas dapat disimpulkan bahwa kinerja (prestasi kerja) auditor adalah suatu hasil karya yang dicapai oleh seorang auditor dalam melaksanakan tugastugas yang dibebankan kepadanya yang didasarkan atas kecakapan, pengalaman dan kesungguhan waktu yang diukur dengan mempertimbangkan kuantitas dan ketepatan waktu. Kinerja dapat diukur melalui pengukuran tertentu (standar) yang mencakup kualitas, kuantitas dan ketepatan waktu. Kualitas berkaitan dengan mutu kerja yang dihasilkan, sedangkan kuantitas adalah jumlah hasil kerja yang dihasilkan dalam kurun waktu tertentu dan ketepatan waktu adalah kesesuaian waktu yang telah direncanakan.

\section{B.2 Unified Theory of Acceptance and Use of Technology (UTAUT)}

Berdasarkan literatur yang sudah ada, Venkatesh et. al. (2003) mengembangkan UTAUT sebagai synthesis (tiruan) penelitian technology acceptance sebelumnya. UTAUT memiliki empat key constructs yang mempengaruhi niat perilaku untuk menggunakan teknologi danpenggunaan teknologi. Keempat kunci pembangun tersebut adalah performance expectancy, effort expectancy, social influence dan facilitating conditions. Tentunya isi dari kunci-kunci ini dapat diadaptasi dan disesuaikan agar sesuai dengan konteks pembahasan.

Menurut UTAUT, performance expectancy, effort expectancy dan social influence diteorikan untuk mempengaruhi niat perilaku untuk menggunakan teknologi, sedangkan niat perilaku dan facilitating conditions menentukan penggunaan teknologi. Dan juga, perbedaan variabel, umur, gender dan pengalaman individual diteorikan untuk memoderasi macam-macam hubungan UTAUT.

\section{B.3 Model Technology Acceptance}

Pennington et al. (2006) dan Schwarz dan Chin (2007) dalam Herusetya (2011) mengungkapkan bahwa penelitian dalam area Technology Acceptance Model (selanjutnya disebut TAM) mencoba untuk memahami faktor-faktor yang mempengaruhi penggunaan teknologi. Model pertama mengenai TAM berasal dari Davis (1989). Pengembangan penelitian yang lebih kaya dilakukan oleh para peneliti information system (IS) (Budiasih, 2002) yang telah menggunakan Theory of Planned Behaviour dengan memasukkan pengaruh normatif dan pengendalian sebagaimana halnya dengan persepsi atas teknologi informasi.

Beberapa peneliti lainnya mencoba mengintegrasikan seluruh elemen dari berbagai model, yang disebut dengan United Theory of Acceptance and Use of Technology (UTAUT) yang dikembangkan oleh 
Venkatesh et al. (2003). TAM mengkonsentrasikan analisis dari perilaku individu dan mencerminkan penerimaan terhadap teknologi yang berbeda.

Kim (2009) mengatakan bahwa Technology Acceptance Model (TAM) adalah suatu model untuk memprediksi dan menjelaskan bagaimana pengguna teknologi menerima dan menggunakan teknologi yang berkaitan dengan pekerjaan pengguna. Model TAM berasal dari teori psikologis untuk menjelaskan perilaku pengguna teknologi informasi yang berlandaskan pada keperacayaan (belief), sikap (attitude), minat (intention) dan hubungan perilaku pengguna (user behavior relationship). Teori ini membuat model perilaku seseorang sebagai suatu fungsi dari tujuan perilaku. Tujuan perilaku ditentukan oleh sikap atas perilaku tersebut.

Moore dan Benhasat (1991) dalam Herusetya

mengembangkan karakteristik teknologi yang dianggap sebagai antecedents adopsi dari teknologi informasi tersebut. Beberapa peneliti lainnya mencoba untuk mengembangkan model dengan mengintegrasikan seluruh elemen dari berbagai model, yang disebut dengan nama United Theory of Acceptance and Use of Technology (UTAUT) dikembangkan oleh Venkatesh et al. (2003). Ajzen dan Fishbein (1980) dalam Supriyanti (2005) mengatakan bahwa TAM merupakan kepanjangan dari Theory of Reasoned Action (TRA), yang menjelaskan perilaku individu berdasarkan keyakinan dan maksud mereka. TAM mengkonsentrasikan analisis dari perilaku individu dan mencerminkan penerimaan terhadap teknologi yang berbeda. TAM menggunakan dua construct kunci, yaitu perceived usefulness (PU) dan perceived ease of use (PEOU) (Davis, 1989). Kedua faktor kunci ini menentukan sikap pengguna terhadap intensitas untuk menggunakan dan pemakaian aktual dari sistem informasi.
Perceived usefulness (PU) atau bisa disebut juga perepsi kegunaan adalah ukuran untuk mengukur seberapa besar pengguna teknologi informasi potensial percaya bahwa penggunaan perangkat khusus tersebut akan meningkatkan kinerja mereka (Davis, 1989; Putra, 2013). Sedangkan perceived ease of use (PEOU) adalah persepsi bahwa menggunakan teknologi khusus tersebut tidak memerlukan tambahan usaha (effort) dalam penggunaannya (Davis, 1989: 320; Kim et al., 2009).

Davis (1989) menunjukkan bahwa, baik PU dan PEOU memiliki pengaruh langsung atas maksud untuk menggunakan dan penggunaan aktual, sedangkan PEOU juga memiliki pengaruh tidak langsung atas intensitas untuk menggunakan dan penggunaan aktual melalui persepsi kegunaan. Studi ini menggunakan sebagian konsep model TAM dari Davis (1989) dengan alasan karena telah digunakan secara luas dan merupakan salah satu model yang sukses digunakan dalam penelitianpenelitian pada masa lampau.

\section{B.4 Pengembangan Hipotesis}

Berdasarkan landasan teori dan penelitian terdahulu seperti yang telah dipaparkan di atas, maka penelitian ini akan menguji pengaruh keahlian dan pengetahuan auditor, penggunaan sistem dan persepsi penggunaan terhadap kinerja auditor dengan rumusan hipotesis sebagai berikut:

\section{B.4.1 Keahlian dan Pengetahuan Auditor}

Skill and knowledge atau keahlian dan pengetahuan auditor yang dimaksud di dalam penelitian ini adalah kemampuan dan keahlian yang dimiliki auditor dalam bidang teknologi informasi. Pemahaman dan penguasaan teknologi informasi ini khususnya adalah terkait dengan sistem teknologi informasi yang diadopsi oleh KAP dimana auditor bekerja.

Menurut Venkatesh et al. (2003) dalam Gautama (2010) bahwa salah satu kunci pembangun Unified 
Theory of Acceptance and Use of Technology (UTAUT) adalah facilitating condition. Faktor ini mempengaruhi niat perilaku untuk menggunakan teknologi dan/atau penggunaan teknologi. Termasuk diantara faktor atau kondisi yang menunjang seseorang (dalam hal ini auditor) untuk menggunakan teknologi informasi dalam pekerjaannya adalah keahlian dan pengetahuan auditor dalam bidang teknologi informasi.

Masing-masing KAP biasanya menggunakan aplikasi sistem teknologi informasi berupa software audit yang berbeda-beda. Pengadopsian sistem teknologi ini bertujuan untuk memudahkan pekerjaan auditor dalam mengaudit. Untuk dapat memanfaatkan kegunaan dari sistem teknologi ini secara optimal maka auditor harus menguasai teknologi informasi yang diadopsi oleh KAP tempatnya bekerja.

Bentuk atau jenis aplikasi software yang digunakan oleh KAP biasanya adalah jenis Group Decision Support System yang memungkinkan pekerjaan tim audit menjadi lebih mudah dan terintegrasi. Berdasarkan uraian di atas, maka dapat dirumuskan hipotesis sebagai berikut:

H1: Keahlian dan pengetahuan auditor berpengaruh positif terhadap kinerja auditor.

\section{B.4.2 Penggunaan Sistem Teknologi Informasi}

Penggunaan sistem teknologi informasi atau TI yang dimaksud dalam penelitian ini adalah apakah staf auditor sudah memanfaatkan atau menggunakan bantuan teknologi tersebut dengan optimal. Masing-masing KAP tentu tidak lepas dari penerapan sistem TI yang terpadu dan dinamis. Apabila tidak dimanfaatkan oleh staf audit yang bekerja di dalamnya, tentu hal tersebut akan menjadi sia-sia.

Davis (1989) dalam Herusetya (2011) menunjukkan bahwa perceived usefulness memiliki pengaruh langsung atas maksud untuk menggunakan dan actual usage. Dengan adanya keterkaitan antara persepsi penggunaan (perceived usefulness) dengan penggunaan system teknologi informasi, maka penelitian ini menggunakan variabel system usage atau penggunaan sistem untuk mengukur seberapa besar intensi responden untuk menggunakan sistem teknologi informasi. System usage atau information system use mengukur seberapa banyak penggunaan dari sistem informasi yang mendukung penugasan dari seorang auditor. Variabel independen ini merupakan variabel kunci yang mengukur seberapa efektif pemanfaatan sumber daya sistem informasi dalam organisasi. Berdasarkan uraian di atas, maka dapat dirumuskan hipotesis sebagai berikut:

H2: Penggunaan sistem teknologi informasi berpengaruh positif terhadap kinerja auditor.

\section{B.4.3 Persepsi Penggunaan}

Menurut Ajzen (1985) dalam Putra (2013) dan O'Brien (2014), persepsi penggunaan berkaitan dengan nilai manfaat yang dirasakan oleh pengguna berkaitan dengan penggunaan suatu teknologi informasi. Pernyataan itu sesuai dengan penelitian Seftriadi (2008) yang menunjukkan bahwa penggunaan teknologi dapat mengurangi waktu yang dibutuhkan seorang auditor melakukan pengolahan data dibanding jika melakukan secara manual.

Variabel ini mengukur seberapa jauh persepsi pengguna sistem informasi percaya bahwa penggunaan sistem tersebut akan meningkatkan kinerja mereka. Adam et al. (1992) dan Davis et al. (1989) di dalam Herusetya (2011) menemukan bahwa persepsi kegunaan merupakan determinan utama dalam perilaku (yaitu penggunaan/system usage). Literatur dalam sistem informasi memberi bukti adanya hubungan positif dengan penggunaan sistem (system usage) (Davis, 1989). Berdasarkan penjelasan tersebut, maka dapat dirumuskan hipotesis sebagai berikut: 
H3:

$$
\begin{array}{lr}
\text { Persepsi } & \text { penggunaan } \\
\text { berpengaruh } & \text { positif } \\
\text { terhadap kinerja auditor. }
\end{array}
$$

\section{METODE PENELITIAN}

\section{C.1 Variabel Penelitian}

Dalam penelitian ini variabelvariabel penelitian diklasifikasikan menjadi dua kelompok, yaitu variabel terikat (dependent variable) dan variabel bebas (independent variable). Variabel dependen pada penelitian ini adalah kinerja auditor atau auditor's performance dan yang menjadi variabel independen adalah skill and knowledge auditor, system usage atau information system use serta perceived usefulness.

\section{C.2 Definisi dan Operasionalisasi Variabel \\ C.2.1 Pengetahuan dan Keahlian Auditor}

Skill and knowledge of auditor adalah keahlian dan pengetahuan auditor dalam bidang teknologi informasi, khususnya sistem teknologi informasi yang diadopsi oleh KAP tempatnya bekerja. Skill and knowledge of auditor selanjutnya akan disingkat skill, dan diukur dengan menggunakan lima pertanyaan yang merupakan variabel teramati dengan modifikasi seperlunya agar relevan dengan tipe responden auditor. Variabel ini menggunakan lima skala Likert, dari skala 1 (sangat tidak setuju) hingga skala 5 (sangat setuju). Semakin tinggi skor variabel ini, menunjukkan semakin tinggi persepsi bahwa keahlian dan pengetahuan auditor dalam bidang teknologi informasi memudahkan pekerjaan mengauditnya atau dengan kata lain memberi pengaruh positif terhadap kinerjanya.

Variabel skill and knowledge ini mengukur tingkat keahlian dan pengetahuan yang dimiliki oleh auditor dalam bidang teknologi informasi. Untuk memudahkan pengukuran, dasar pemikiran ini dibagi ke dalam lima pertanyaan. Kelima pertanyaan dalam kuesioner penelitian ini menanyakan seputar kemampuan responden dalam mengoperasikan komputer beserta aplikasinya, latar belakang pendidikan responden di bidang TI dan pertanyaan seputar software audit.

\section{C.2.2 Penggunan Sistem}

System usage atau information system use mengukur seberapa banyak penggunaan dari sistem informasi yang mendukung penugasan dari seorang auditor. Variabel ini disingkat usage, dan merupakan variabel kunci yang mengukur seberapa efektif pemanfaatan sumber daya sistem informasi dalam organisasi. System usage diamati dengan variabel teramati yang disingkat USE, dan diukur dengan menggunakan empat pertanyaan sebagai variabel teramati dengan modifikasi seperlunya agar sesuai dengan tipe responden auditor. Pengukuran ini menggunakan lima skala Likert.

Seperti yang sudah dipaparkan pada paragraf sebelumnya, variabel ini mengukur seberapa banyak penggunaan dari system informasi untuk mendukung penugasan seorang auditor. Oleh karena tujuan dari pengukuran adalah untuk mencari tahu frekuensi penggunaan teknologi informasi, maka skala pengukuran pun disesuaikan menjadi Tidak Pernah (TP), Jarang (J), Kadang-kadang (K), Sering (S), Selalu (SL). Pertanyaan yang diajukan adalah seputar frekuensi penggunaan komputer, e-mail, internet dan electronic groupware oleh responden.

\section{C.2.3 Persepsi Penggunaan}

Persepsi penggunaan mengukur seberapa jauh persepsi pengguna sistem informasi percaya bahwa penggunaan sistem tersebut akan meningkatkan kinerja mereka. Adam et al. (1992) dan Davis et al. (1989) di dalam Herusetya (2011) menemukan bahwa perceived usefulness merupakan determinan utama dalam perilaku (yaitu penggunaan/system usage). Literatur dalam sistem informasi memberi bukti adanya hubungan positif dengan penggunaan sistem (system usage) (Davis, 1989; Igbaria, 1990 dalam Igbaria dan Tan, 1997). 
Variabel ini disingkat peruseful, dan diukur dengan menggunakan enam pertanyaan sebagai variabel teramati dengan modifikasi seperlunya agar sesuai dengan tipe responden auditor. Pengukuran ini menggunakan lima skala Likert.

Berdasarkan pengertian yang telah dipaparkan di atas, pertanyaan dalam kuesioner untuk variabel ini dibagi menjadi enam bagian. Pertanyaan-pertanyaan pada bagian ini berkisar tentang keuntungan dalam menggunakan teknologi informasi dari sisi waktu, penyimpanan data, pengalaman, efektivitas dan efisiensi dalam pembuatan kertas kerja, problem analysis dan pembuatan keputusan. Skala pengukuran dimulai dari sangat tidak setuju, tidak setuju, netral, setuju hingga sangat setuju dengan skor berurutan mulai dari 1 sampai 5 .

\section{C.2.4 Auditor's Performance}

Auditor's performance atau kinerja auditor merupakan suatu ukuran efektivitas dan efisiensi dari pekerjaan auditor dalam menyelesaikan tugas auditnya. Kinerja dapat diukur melalui pengukuran tertentu (standar) yang mencakup kualitas, kuantitas dan ketepatan waktu. Kualitas berkaitan dengan mutu kerja yang dihasilkan, sedangkan kuantitas adalah jumlah hasil kerja yang dihasilkan dalam kurun waktu tertentu dan ketepatan waktu adalah kesesuaian waktu yang telah direncanakan.

Menurut penelitian sebelumnya disebutkan bahwa terdapat hubungan antara penggunaan (usage) teknologi informasi dengan kinerja auditor. Kinerja auditor akan meningkat seiring dengan optimalnya pemanfaatan sistem teknologi informasi yang menunjang pekerjaan seorang auditor. Untuk memudahkan pengukuran, maka variabel ini diterjemahkan menjadi tujuh pertanyaan kuesioner. Pertanyaan yang diajukan adalah seputar apakah responden merasakan berbagai keuntungan atau manfaat dari teknologi informasi yang berbanding lurus dengan kinerja responden sebagai auditor. Untuk pertanyaanpertanyaan yang diberikan tadi, disediakan dua pilihan jawaban yaitu Ya atau Tidak.

\section{C.3 Model Penelitian}



Gambar 1

Kerangka Konseptual Penelitian

Sumber: Diolah penulis, 2018 


\section{C.4 Populasi dan Sampel}

Populasi dalam penelitian ini adalah Kantor Akuntan Publik (KAP) yang terdapat di Kota Makassar. Sampel pada penelitian ini adalah 45 auditor yang bekerja di KAP di Kota Makassar. Metode pengambilan sampel menggunakan metode purposive sampling. Metode purposive sampling adalah teknik penentuan sampel yang didasarkan pada tujuan tertentu.

\section{C.5 Metode Pengumpulan Data}

Penelitian ini menggunakan data primer dengan metode survey. Kuesioner penelitian dibagikan langsung di lapangan kepada responden pada KAP di Kota Makassar. Kuesioner penelitian ini merupakan pengembangan dari berbagai instrumen pengukuran yang telah digunakan peneliti sebelumnya. Pengisian kuesioner dilakukan secara langsung oleh responden dan diawasi secara langsung pengembalian dan kelengkapan pengisiannya oleh peneliti.

\section{C.6 Metode Analisis Data}

Untuk menguji seberapa besar pengaruh variabel bebas (X1, X2 dan X3) terhadap variabel Y maka akan diuji dengan analisis regresi berganda dengan rumus sebagai berikut:

$\mathrm{Y}=\mathrm{a}+\mathrm{b}_{1} \mathrm{X}_{1}+\mathrm{b}_{2} \mathrm{X}_{2}+\mathrm{b}_{3} \mathrm{X}_{3}+\hat{\mathrm{e}}$

Keterangan:

$\mathrm{Y}=$ Kinerja Auditor

$\mathrm{a}=$ Konstanta

$\mathrm{b}=$ Koefisien dari variabel bebas

$\mathrm{X}_{1}=$ Koefisien regresi variabel skill \& knowledge

$\mathrm{X}_{2}=$ Koefisien regresi variabel system usage

$\mathrm{X}_{3}=$ Koefisien regresi variabel perceived usefulness

$\mathrm{e}=$ Standard error

\section{HASIL DAN PEMBAHASAN}

\section{D.1 Deskripsi Obyek Penelitian}

Terdapat 45 orang auditor sebagai populasi penelitian dari tujuh KAP berbeda di Makassar. Auditor yang dijadikan sampel dari KAP.

Tabel 1

Statistik Deskriptif

\begin{tabular}{|l|c|c|c|c|c|c|c|}
\hline $\begin{array}{c}\text { Statistik } \\
\text { Deskriptif } \\
\text { Variabel }\end{array}$ & $\begin{array}{c}\text { Teoritis } \\
\text { Min }\end{array}$ & $\begin{array}{c}\text { Teoritis } \\
\text { Maks }\end{array}$ & $\begin{array}{c}\text { Empiris } \\
\text { Min }\end{array}$ & $\begin{array}{c}\text { Empiris } \\
\text { Maks }\end{array}$ & $\begin{array}{c}\text { Mean } \\
\text { Teoritis }\end{array}$ & $\begin{array}{c}\text { Mean } \\
\text { Empiris }\end{array}$ & $\begin{array}{c}\text { Standar } \\
\text { Deviasi }\end{array}$ \\
\hline $\begin{array}{l}\text { Skill and } \\
\text { Knowledge }\end{array}$ & 5 & 25 & 7 & 22 & 15 & 17,956 & 4,216 \\
\hline $\begin{array}{l}\text { System } \\
\text { Usage }\end{array}$ & 4 & 20 & 6 & 20 & 12 & 14,933 & 3,683 \\
\hline $\begin{array}{l}\text { Perceived } \\
\text { Usefulness }\end{array}$ & 6 & 30 & 10 & 29 & 18 & 22,333 & 5,231 \\
\hline $\begin{array}{l}\text { Kinerja } \\
\text { Auditor }\end{array}$ & 7 & 14 & 7 & 14 & 10,5 & 11,578 & 2,426 \\
\hline
\end{tabular}

Sumber: Diolah penulis, 2017

Dari tabel 1 dapat dilihat bahwa nilai terendah variabel Keahlian dan Pengetahuan sebesar 7 sedangkan nilai tertinggi sebesar 22 dengan nilai rata-rata teoritis 15 , nilai rata-rata empiris 17,956 dan standar deviasinya 4,216. Nilai terendah variabel Penggunaan Sistem sebesar 6 sedangkan nilai tertinggi sebesar 20 dengan nilai rata-rata teoritis 12 , nilai rata-rata empiris 14,933 dan standar deviasinya 3,683. Nilai terendah variabel Persepsi Penggunaan sebesar 10 sedangkan nilai tertinggi sebesar 29 dengan nilai rata-rata teoritis 18 , nilai rata-rata empiris 22,333 dan 
standar deviasinya 5,231. Nilai terendah variabel Kinerja Auditor sebesar 7 sedangkan nilai tertinggi sebesar 14 dengan nilai rata-rata teoritis 10,5 , nilai rata-rata empiris 11,578 dan standar deviasinya 2,426. Untuk menilai bahwa suatu nilai rata-rata empiris termasuk ke dalam suatu golongan ukuran (misalnya tinggi atau rendah), maka perlu dibuat suatu indeks. Rumusnya adalah selisih antara nilai rata-rata teoritis maksimum dikurangi nilai rata-rata teoritis minimum lalu dibagi ke dalam kelas yang diinginkan. Untuk memudahkan pengamatan, maka dibuatlah 4 kelas untuk pengukuran dalam penelitian ini.

Tabel 2

Indeks Skor Variabel

\begin{tabular}{|l|c|c|c|c|}
\hline $\begin{array}{c}\text { Indeks Skor } \\
\text { Variabel }\end{array}$ & Rendah & Sedang & Tinggi & $\begin{array}{c}\text { Sangat } \\
\text { Tinggi }\end{array}$ \\
\hline X1 & $5-9$ & $10-14$ & $15-19$ & 20 \\
\hline X2 & $4-7$ & $8-11$ & $12-15$ & 16 \\
\hline X3 & $6-11$ & $12-17$ & $18-23$ & 24 \\
\hline
\end{tabular}

Sumber: Diolah penulis, 2017

Berdasarkan tabel 2 di atas, dapat disimpulkan bahwa nilai ratarata empiris variabel keahlian dan pengetahuan auditor yang sebesar 17,956 masuk ke dalam golongan tinggi. Nilai rata-rata empiris variabel penggunaan sistem yang sebesar 14,933 juga masuk ke dalam kelas atau golongan tinggi. Variabel independen ketiga yaitu persepsi penggunaan dengan nilai rata-rata empiris sebesar 22,333 pun termasuk ke dalam golongan tinggi.

\section{D.2 Uji Hipotesis}

Uji $F$ dilakukan untuk mengetahui apakah variabel independen secara bersama-sama berpengaruh signifikan terhadap variabel dependen. Pengujian ini menggunakan tingkat signifikansi 0,05 . Berikut ini hasil penghitungan uji F.

Tabel 3

Hasil Analisis Regresi Secara Simultan (Uji F)

\begin{tabular}{|c|c|c|c|c|}
\hline $\begin{array}{c}\text { Hasil Analisis Regresi Secara } \\
\text { Simultan (Uji F) Model }\end{array}$ & $\mathbf{R}$ & $\begin{array}{c}\mathbf{R} \\
\text { Square }\end{array}$ & $\begin{array}{c}\text { Adjusted R } \\
\text { Square }\end{array}$ & $\begin{array}{c}\text { Std. Error of } \\
\text { the Estimate }\end{array}$ \\
\hline 1 & 0,855 & 0,731 & 0,705 & 1,112 \\
\hline
\end{tabular}

Sumber: Diolah penulis, 2017

Dari tabel di atas juga diketahui pengaruh ketiga variabel bebas terhadap variabel Kinerja Auditor dinyatakan dengan nilai Adjusted $R^{2}$, yaitu 0,705 atau 70,5 persen. Hal ini berarti sebesar 70,5 persen variasi yang terjadi pada variabel Kinerja Auditor disebabkan oleh pengaruh variabel $\mathrm{X} 1, \mathrm{X} 2$ dan $\mathrm{X} 3$ secara simultan. Dengan demikian masih terdapat sebesar $100 \%-70,5 \%=29,5$ persen yang merupakan kontribusi variabel bebas lain di luar X1, X2 dan X3. Koefisien regresi berganda $R$ sebesar 0,855, oleh karena $R$ tidak memiliki negasi untuk menolak atau menerima hipotesis penelitian, maka diperlukan perubahan koefisien regresi berganda $R$ ke dalam uji $F$, sebagaimana tabel di bawah. 
Tabel 4

ANOVA

\begin{tabular}{|l|l|l|l|c|c|}
\hline $\begin{array}{c}\text { ANOVA } \\
\text { Model }\end{array}$ & $\begin{array}{c}\text { Sum of } \\
\text { Squares }\end{array}$ & Df & Mean Square & F & Sig. \\
\hline Regression & 207,100 & 3 & 69,033 & 52,545 & 0,000 \\
Residual & 51,878 & 41 & 1,265 & & \\
\hline Total & 258,978 & 44 & & & \\
\hline
\end{tabular}

Sumber: Diolah penulis, 2017

Berdasarkan perhitungan dengan uji $\mathrm{F}$ diperoleh nilai $\mathrm{F}$ sebesar 52,545 dengan signifikansi (sig) sebesar 0,000 . Oleh karena sig sebesar 0,000 $<$ 0,05, maka kesimpulan yang diambil adalah menerima hipotesis penelitian. Dengan kata lain, X1, X2 dan X3 secara simultan berpengaruh secara signifikan terhadap variabel Kinerja Auditor (Y).

Tabel 5

Hasil Uji T

\begin{tabular}{|c|c|c|c|c|c|c|c|}
\hline Model & $\begin{array}{c}\text { Unstand } \\
\text { ardized } \\
\text { b }\end{array}$ & $\begin{array}{c}\text { Coefficie } \\
\text { ntsStd. } \\
\text { Error }\end{array}$ & $\begin{array}{c}\text { Unstandard } \\
\text { ized } \\
\text { Coefficient } \\
\text { s Beta }\end{array}$ & $\mathrm{t}$ & Sig. & $\begin{array}{c}\text { Colline } \\
\text { arityTo } \\
\text { lerance }\end{array}$ & $\begin{array}{c}\text { Statis } \\
\text { ticsVI } \\
\text { F }\end{array}$ \\
\hline $\begin{array}{c}\text { Skill and } \\
\text { Knowledge }\end{array}$ & 0,230 & 0,097 & 0,413 & 2,56 & 0,015 & 0,200 & 5,011 \\
\hline $\begin{array}{c}\text { System } \\
\text { Usage }\end{array}$ & 0,175 & 0,073 & 0,254 & 2,32 & 0,020 & 0,390 & 2,565 \\
\hline $\begin{array}{c}\text { Perceived } \\
\text { Usefulness }\end{array}$ & 0,134 & 0,067 & 0,234 & 2,13 & 0,049 & 0,249 & 4,018 \\
\hline
\end{tabular}

Sumber: Diolah penulis, 2017

Dari tabel di atas diketahui hasil koefisien beta dan $\mathrm{t}$ memiliki angka yang positif maka dapat diketahui bahwa pengaruh antar variabel ini positif. Diketahui pula ketiga variabel memiliki nilai signifikansi kurang dari 0,05 sehingga dapat ditarik kesimpulan bahwa keseluruh variabel independen berpengaruh positif terhadap variabel Kinerja Auditor. Sementara itu besarnya pengaruh variabel independen terhadap variabel dependen dapat dilihat dari skor beta yang terdapat dalam tabel di atas. Dari tabel diketahui bahwa besar pengaruh variabel keahlian dan pengetahuan (Skill and Knowledge) sebesar 41,3\%, penggunaan system (System Usage) sebesar 25,4\% dan variabel persepsi penggunaan (Perceived Usefulness) sebesar 23,4\% terhadap variabel kinerja auditor.

\section{E. PENUTUP}

\section{E.1 Kesimpulan}

Berdasarkan hasil analisis data yang diperoleh, selanjutnya dapat disimpulkan sebagai berikut ini:

1. Skill and knowledge memiliki pengaruh yang signifikan terhadap kinerja auditor dengan arah positif. Hal ini berarti semakin banyak atau luas pengetahuan dan kemampuan auditor di bidang TI, maka akan semakin baik pula kinerjanya dalam mengaudit.

2. System usage memiliki pengaruh terhadap kinerja auditor dengan arah positif. Hal ini berarti responden telah secara aktif menggunakan atau memanfaatkan fasilitas teknologi informasi dalam menunjang pekerjaannya sebagai seorang auditor. 
3. Perceived usefulness memiliki pengaruh yang signifikan terhadap kinerja auditor dengan arah positif. Hal ini berarti responden atau auditor meyakini bahwa teknologi informasi bermanfaat dalam membantu menyelesaikan tugastugas atau pekerjaan mereka sebagai auditor.

\section{E.2 Saran} ini:

Adapun saran dalam penelitian

1. Menambahkan variabel atau indikator lain dalam penelitian selanjutnya.

2. Memperluas daerah penelitian menjadi lingkup Propinsi Sulawesi Selatan.

3. Sebaiknya metode pengumpulan data diubah menjadi metode wawancara agar terjadi kesamaan perspektif dan hasil pengumpulan data menjadi lebih efektif.

\section{DAFTAR PUSTAKA}

Arens et al., 2011,Jasa Audit dan Assurance: Pendekatan Terpadu (Adaptasi Indonesia), Jakarta, Salemba Empat.

Bodnar, G.H. dan W. Hoopwoods, 2006, Sistem Informasi Akuntansi, Jakarta,Salemba Empat.

Budiasih, 2002, Dampak Perkembangan Teknologi Informasi Terhadap Sistem Informasi Akuntansi. Jurnal Ekonomi dan Bisnis Universitas Gunadarma, 7, p 117-130.

Davis, F. D, 1989, Perceived Usefulness, Perceived Ease of Use and User Acceptance of Information Technology. Management Information System Quarterly, 4.

Davis, Gordon B dan Margareth $\mathrm{H}$ Olson, 2005, Management Information System, New York, Addison Wesley Publishing Inc.
Eliza, Colins G. C. dan Anne Devanna Mary, 1992, The Portabble MBA, New York, Johar Wiley and Sons Inc.

Galung, 2009, Pengaruh Pemanfaatan Teknologi Informasi dan Kepuasan Kompensasi Terhadap Kinerja Auditor BPK-RI Perwakilan Provinsi Aceh, Banda Aceh.

Esya, F.P., 2008, Pengaruh Kompetensi Auditor dan Pemahaman Sistem Informasi Akuntansi Terhadap Kinerja Auditor Bea dan Cukai di Wilayah Jakarta, Tesis, Sekolah Pascasarjana Universitas Sumatera Utara, Medan.

Fleenor, W. C., 2002, Implication on Computers in Financial Statement Audits, Journal of Accountancy New York, 179, p 9193.

Gautama I. dan M. Arfan, 2010, Pengaruh Kepuasan Kerja, Profesionalisme dan Teknologi Informasi terhadap Kinerja Auditor (Studi pada Kantor BPK RI Perwakilan Provinsi Aceh), Jurnal Telaah dan Riset Akuntansi, 3, p 195-205.

Ghozali, Imam, 2007, Aplikasi Analisis Multivariate dengan Program SPSS, Semarang, Badan Penerbit Universitas Diponegoro.

Herusetya, 2011, Pengaruh Penerapan Teknologi Informasi pada KAP Big 4 di Indonesia, Jurnal Media Riset Akuntansi, 2.

Kim H. J, Mannino M., dan Nieschwietz R. J., 2009, Information Technology Acceptance in The Internal Audit Profession: Impact of Technology Features and Complexity. International Journal of Accounting Information System, 10, p 214-228. 
Mangkunegaran, A. P., 2005, Evaluasi Kinerja SDM, Bandung, Refika Aditama.

Mayangsari, S., 2003, Pengaruh Keahlian dan Independensi terhadap Pendapat Audit: Sebuah Kuasi Eksperimen. Jurnal Riset Akuntansi Indonesia, 6, p 1-22.
O'Brien, J. dan G. Marakas, 2014, Sistem Informasi Manajemen, Jakarta, Salemba Empat.

Putra dan Noviasari, 2013, Pemanfaatan Teknologi Informasi, Kepercayaan dan Kompetensi pada Penerapan Teknik Audit Sekitar Komputer. E-Jurnal Akuntansi Universitas Udayana, 4, p 640-654.

Sekaran, U., 2006, Research Methods For Business, Jakarta, Salemba Empat.
Seftriadi, 2008, Pengaruh Keahlian dalam Penggunaan Sistem Informasi terhadap Kinerja Auditor pada Kantor Perwakilan BPK-RI di Wilayah Sumatera Bagian Utara, Tesis, Universitas Sumatera Utara, Medan.

Suaib, M.R., 2008, Pengaruh Lingkungan, Perilaku, Struktur Organisasi dan Implementasi Sistem Informasi Berbasis Komputer terhadap Kinerja Karyawan. Jurnal Aplikasi Manajemen, 6, p123-130.

Sugiyono, 2009, Metode Penelitian Bisnis, Bandung, Alfabeta.

Supriyati, 2005, Peranan Teknologi Informasi Dalam Audit Sistem Informasi Komputerisasi Akuntansi, Majalah Imiah Unikom, 6,p 35-50. 